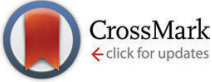

Cite this: Phys. Chem. Chem. Phys., $2015,17,28088$

Received 16th January 2015, Accepted 2nd March 2015

DOI: $10.1039 / c 5 c p 00282 f$

www.rsc.org/pccp

\section{Gas phase selective hydrogenation over oxide supported $\mathrm{Ni}-\mathrm{Au}$}

\author{
Fernando Cárdenas-Lizana and Mark A. Keane*
}

The chemoselective continuous gas phase ( $T=573 \mathrm{~K} ; P=1 \mathrm{~atm}$ ) hydrogenation of nitroarenes ( $p$-chloronitrobenzene $\left(p\right.$-CNB) and $m$-dinitrobenzene $\left(m\right.$-DNB)) has been investigated over a series of oxide $\left(\mathrm{Al}_{2} \mathrm{O}_{3}\right.$ and $\left.\mathrm{TiO}_{2}\right)$ supported $\mathrm{Au}$ and $\mathrm{Ni}-\mathrm{Au}(1: 10 \mathrm{~mol}$ ratio; 0.1-1 mol\% Au) catalysts. Monometallic supported $\mathrm{Au}$ with mean particle size 3-9 $\mathrm{nm}$ promoted exclusive formation of $p$-chloroaniline ( $p$-CAN) and $m$-nitroaniline ( $m$-NAN). Selective hydrogenation rate was higher over smaller Au particles and can be attributed to increased surface hydrogen (from TPD measurements) at higher metal dispersion. (S)TEM analysis has confirmed an equivalent metal particle size for the supported bimetallics at the same $\mathrm{Au}$ loading where TPR indicates $\mathrm{Ni}-\mathrm{Au}$ interaction and EDX surface mapping established $\mathrm{Ni}$ in close proximity to $\mathrm{Au}$ on isolated nanoparticles with a composition ( $\mathrm{Au} / \mathrm{Ni}$ ) close to the bulk value $(=10$ ). Increased spillover hydrogen due to the incorporation of $\mathrm{Ni}$ in the bimetallics resulted in elevated $-\mathrm{NO}_{2}$ group reduction rate. Full selectivity to $p$-CAN was maintained over all the bimetallic catalysts. Conversion of $m$-DNB over the lower loaded $\mathrm{Ni}-\mathrm{Au} / \mathrm{Al}_{2} \mathrm{O}_{3}$ generated $m-\mathrm{NAN}$ as sole product. An increase in $\mathrm{Ni}$ content $(0.01 \rightarrow 0.1 \mathrm{~mol} \%)$ or a switch from $\mathrm{Al}_{2} \mathrm{O}_{3}$ to $\mathrm{TiO}_{2}$ as support resulted in full $-\mathrm{NO}_{2}$ reduction (to $\mathrm{m}$-phenylenediamine). Our results demonstrate the viability of $\mathrm{Ni}$-promotion of $\mathrm{Au}$ in the continuous production of functionalised anilines.

\section{Introduction}

The combination of two metallic elements has been shown to be an effective means of improving catalytic performance in a range of hydrogen mediated reactions, notably chemoselective hydrogenation (of nitro-compounds ${ }^{1}$ ), partial hydrogenation (of alkynes ${ }^{2}$ ) and hydrogenolysis (of chlorophenols ${ }^{3}$ ). Renewed interest in $\mathrm{Au}$ as a catalytic agent has encompassed $\mathrm{Au}$ in bimetallic formulations, as noted in the recent review by Villa et al. ${ }^{4}$ Gold has shown unique selectivity in the hydrogenation of polyfunctional reactants but delivers low reaction rates. ${ }^{5}$ This drawback has been ascribed to a restricted capacity for $\mathrm{H}_{2}$ activation by dissociative chemisorption. ${ }^{6}$ The combination of Au with transition metals that exhibit greater $\mathrm{H}_{2}$ chemisorption capability offers a possible means of enhancing hydrogenation rate.

The hydrogenation response over bimetallic catalysts is determined by the structure and physico-chemical properties of the supported nanoparticles, which are dependent on the distribution of both metals within the crystal nanostructure. In order to achieve any degree of catalytic synergy, the two metals must be in close proximity (if not in direct contact) on the support. The size, metal ratio and nature of the support are

Chemical Engineering, School of Engineering and Physical Sciences, Heriot-Watt University, Edinburgh, EH14 4AS, Scotland.E-mail: M.A.Keane@hw.ac.uk; Tel: $+44(0) 1314514719$ critical variables. Bimetallic particles at the nano-scale $(\sim 3 \mathrm{~nm})$ can form solid solutions (homogeneous alloy particles) regardless of the miscibility gap between the two metallic elements. ${ }^{7}$ The incorporation of a second metal with $\mathrm{Au}(\mathrm{X}-\mathrm{Au}$, where $\left.\mathrm{X}=\mathrm{Pd},{ }^{8} \mathrm{Pt}^{9}\right)$ has been shown to increase hydrogenation activity but at low $\mathrm{Au} / \mathrm{X}$ ratios the selectivity response is affected or even governed by the second metal. ${ }^{8,9}$ The redox character and acidbase properties of the (oxide) carrier can act to stabilize small $\mathrm{Au}$ nanoparticles as a result of electron transfer across the metalsupport interface and induce geometric and electronic modifications that impact on catalysis. ${ }^{5}$

Prior research has focused on binary metals that form (ordered or random) bulk alloys with no miscibility gap in the corresponding bulk phase diagram. This is the case with $\mathrm{Pd}-\mathrm{Au}$ as the most widely studied Au-containing bimetallic. ${ }^{10}$ Interest has shifted to systems such as Ni-Au that do not mix in the bulk but can form stable alloys in the outermost surface layers. ${ }^{11,12}$ The incorporation of $\mathrm{Au}$ onto partially oxidised $\mathrm{Ni}$ resulted in partial oxidation of $\mathrm{Au}$ atoms and the formation of $\mathrm{Au}_{n}-\mathrm{O}-\mathrm{Ni}_{m}$ ensembles (from XPS) ${ }^{13}$ which were suggested as active sites in the isomerisation of methylstyrenes over $\mathrm{Ni}-\mathrm{Au} / \mathrm{SiO}_{2} \cdot{ }^{14}$ Nishikawa et al. ${ }^{15}$ studying the promotional effect of $\mathrm{Au}$ on $\mathrm{Ni}$, demonstrated (by XRD, TEM, XAFS and ${ }^{197} \mathrm{Au}$ Mössbauer) the formation of

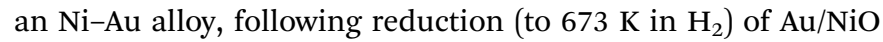
co-precipitates. These were active in the hydrogenolysis of benzylic alcohols with superior catalytic activity compared with RANEY ${ }^{\mathbb{R}} \mathrm{Ni}$. 
Chin et $a .^{16}$ demonstrated by EXAFS/XANES analysis of $\mathrm{Ni}-\mathrm{Au} / \mathrm{MgAl}_{2} \mathrm{O}_{4}$ (prepared by reductive deposition of $\mathrm{Au}$ on $\left.\mathrm{Ni} / \mathrm{MgAl}_{2} \mathrm{O}_{4}\right) \mathrm{Au} \rightarrow \mathrm{Ni}$ electron transfer with surface alloy formation that served to inhibit carbon deposition during $n$-butane steam reforming. The addition of $\mathrm{Au}$ to $\mathrm{Ni}(1: 4)$ resulted in the formation of nano-crystals with a Au-core and Ni-enriched shell structure (based on EXAFS, XPS and UV-vis) with increased hydrogenolysis activity in the conversion of 2-phenoxy-1-phenylethanol. ${ }^{17}$

We have previously examined the catalytic action of supported $\mathrm{Ni}-\mathrm{Au}$ with $\mathrm{Ni} / \mathrm{Au} \mathrm{mol} / \mathrm{mol}=10$ in promoting gas phase nitroarene hydrogenation. ${ }^{18,19}$ That work was directed at the continuous selective production of industrially important functionalised amines under mild reactions conditions. Supported $\mathrm{Ni}-\mathrm{Au}$ delivered higher hydrogenation activities but was less selective than supported Au. We have refocused our attention and have considered the possible role of $\mathrm{Ni}$ (introduced as the minor component; $\mathrm{Ni} / \mathrm{Au} \mathrm{mol} / \mathrm{mol}=0.1$ ) to enhance the chemoselective hydrogenation action of Au to deliver enhanced rates to the target amine product. We assess the feasibility of controlling hydrogenation rate by varying Au particle size and the nature of the oxide support.

\section{Experimental}

\subsection{Catalyst preparation and activation}

The $\mathrm{Al}_{2} \mathrm{O}_{3}$ (Puralox, Condea Vista Co.) and $\mathrm{TiO}_{2}$ (Degussa) supports were used as received. High (HL, $0.1 \mathrm{~mol} \%$ ) and low loaded (LL, $0.01 \mathrm{~mol} \%$ ) $\mathrm{Ni} / \mathrm{Al}_{2} \mathrm{O}_{3}$ and/or $\mathrm{Ni} / \mathrm{TiO}_{2}$ catalyst precursors were synthesised by standard impregnation, where the support ( $6 \mathrm{~g}$ ) was contacted with an aqueous $\mathrm{Ni}\left(\mathrm{NO}_{3}\right)_{2}$ solution (Aldrich, $7 \times 10^{-5}-7 \times 10^{-4} \mathrm{M}, 85 \mathrm{~cm}^{3}$ ). The slurry was heated $\left(2 \mathrm{~K} \mathrm{~min}^{-1}\right)$ to $353 \mathrm{~K}$ and maintained under constant agitation $(600 \mathrm{rpm})$ in a He purge. The solid was dried in a flow of $\mathrm{He}$ at $383 \mathrm{~K}$ for $5 \mathrm{~h}$ and sieved (ATM fine test sieves) to mean particle diameter $=75 \mu \mathrm{m}$. The $\mathrm{Au}-\mathrm{Ni}$ catalyst precursors were prepared by first reducing a batch of ( $\mathrm{LL}$ and $\mathrm{HL}$ ) $\mathrm{Ni} / \mathrm{Al}_{2} \mathrm{O}_{3}$ and (LL) $\mathrm{Ni} / \mathrm{TiO}_{2}$ in a $\left(60 \mathrm{~cm}^{3} \mathrm{~min}^{-1}\right) \mathrm{H}_{2}$ stream at $2 \mathrm{~K} \mathrm{~min}^{-1}$ to $723 \mathrm{~K}$, which was maintained for $1 \mathrm{~h}$ to ensure formation of zero valent $\mathrm{Ni}^{20}$ The gas flow was switched to He, cooled to ambient temperature and the samples passivated in $1 \% \mathrm{v} / \mathrm{v} \mathrm{O}_{2} / \mathrm{He}$. This treatment served to provide a protective oxide layer over the surface Ni that prevented bulk oxidation upon exposure to the atmosphere. The passivated samples were treated with an aqueous $\mathrm{HAuCl}_{4}$ solution (Aldrich, $3 \times 10^{-5}-5 \times 10^{-4} \mathrm{M}, 85 \mathrm{~cm}^{3}$ ) to deliver a 10/1 Au/Ni mol ratio, post-treatment as above. Monometallic (HL, $1 \mathrm{~mol} \%$ and $\mathrm{LL}, 0.1 \mathrm{~mol} \%$ ) $\mathrm{Au} / \mathrm{Al}_{2} \mathrm{O}_{3}$ and (LL, $0.1 \mathrm{~mol} \%$ ) $\mathrm{Au} / \mathrm{TiO}_{2}$ were prepared by standard impregnation with aqueous $\mathrm{HAuCl}_{4}$ (Aldrich, $7 \times 10^{-4}-7 \times 10^{-3} \mathrm{M}, 85 \mathrm{~cm}^{3}$ ). Bulk metal loading was determined by ICP-OES (Vista-PRO, Varian Inc.). The Au-containing samples were stored under He in the dark at $277 \mathrm{~K}$ to avoid the deleterious effects of light (photodecomposition of cationic gold to $\left.\mathrm{Au}^{0}\right)^{21}$ and temperature (aggregation of $\mathrm{Au}$ precursor species). ${ }^{22}$ Before reaction, the catalyst precursors were activated in $60 \mathrm{~cm}^{3} \mathrm{~min}^{-1} \mathrm{H}_{2}$ at $2 \mathrm{~K} \mathrm{~min}^{-1}$ to $723 \mathrm{~K}\left(\mathrm{Ni} / \mathrm{Al}_{2} \mathrm{O}_{3}\right.$ and $\left.\mathrm{Ni} / \mathrm{TiO}_{2}\right)$ or $603 \mathrm{~K}\left(\mathrm{Au} / \mathrm{Al}_{2} \mathrm{O}_{3}, \mathrm{Au} / \mathrm{TiO}_{2}\right.$, $\mathrm{Ni}-\mathrm{Au} / \mathrm{Al}_{2} \mathrm{O}_{3}, \mathrm{Ni}-\mathrm{Au} / \mathrm{TiO}_{2}$ ), which was maintained for $1 \mathrm{~h}$.

\subsection{Catalyst characterisation}

Specific surface area (SSA) and total pore volume measurements were made on a Micromeritics Flowsorb II 2300 unit. Prior to analysis, the samples were outgassed at $423 \mathrm{~K}$ for $1 \mathrm{~h}$ in $20 \mathrm{~cm}^{3} \min ^{-1} \mathrm{~N}_{2}$. SSA was obtained in a $30 \% \mathrm{v} / \mathrm{v} \mathrm{N}_{2} / \mathrm{He}$ flow $\left(20 \mathrm{~cm}^{3} \mathrm{~min}^{-1}\right)$ with at least three cycles of $\mathrm{N}_{2}$ adsorptiondesorption using the standard single-point BET method. Total pore volume was obtained at a relative $\mathrm{N}_{2}$ pressure $\left(P / P_{0}\right)=0.95$. The data were reproducible to $\pm 3 \%$ and values quoted in this paper are the mean.

Temperature programmed reduction (TPR), $\mathrm{H}_{2}$ chemisorption and temperature programmed desorption (TPD) were determined using the CHEM-BET 3000 (Quantachrome) unit. The samples were loaded into a U-shaped Quartz cell (3.76 $\mathrm{mm}$ i.d.) and heated in $17 \mathrm{~cm}^{3} \mathrm{~min}^{-1} 5 \% \mathrm{v} / \mathrm{v} \mathrm{H}_{2} / \mathrm{N}_{2}$ (Brooks mass flow controlled) to $603 \pm 1 \mathrm{~K}\left(\mathrm{Au} / \mathrm{Al}_{2} \mathrm{O}_{3}, \mathrm{Au} / \mathrm{TiO}_{2}, \mathrm{Ni}-\mathrm{Au} / \mathrm{Al}_{2} \mathrm{O}_{3}\right.$ and $\left.\mathrm{Ni}-\mathrm{Au} / \mathrm{TiO}_{2}\right)$ or $723 \pm 1 \mathrm{~K}\left(\mathrm{Ni} / \mathrm{Al}_{2} \mathrm{O}_{3}\right.$ and $\left.\mathrm{Ni} / \mathrm{TiO}_{2}\right)$ at $2 \mathrm{~K} \mathrm{~min}^{-1}$. The effluent gas passed through a liquid $\mathrm{N}_{2}$ trap and $\mathrm{H}_{2}$ consumption was monitored by a thermal conductivity detector (TCD) with data acquisition/manipulation using the TPR Win ${ }^{\mathrm{TM}}$ software. The reduced samples were maintained at the final temperature in $\mathrm{H}_{2}$ until return to baseline. After the reduction step, the samples were cooled in a He flow and subjected to $\mathrm{H}_{2}$ chemisorption (at ambient temperature) using a pulse $(10 \mu \mathrm{l})$ titration procedure, as described elsewhere. ${ }^{23}$ TPD was conducted in a $\mathrm{N}_{2}$ flow $\left(65 \mathrm{~cm}^{3} \mathrm{~min}^{-1}\right)$ at $50 \mathrm{~K} \mathrm{~min}^{-1}$ to $873 \mathrm{~K}$ with an isothermal hold until the signal returned to the baseline. The support alone was subjected to an equivalent TPR and subsequent TPD, which was used to correct for $\mathrm{H}_{2}$ desorption from $\mathrm{Al}_{2} \mathrm{O}_{3} \cdot{ }^{24}$

Metal particle morphology, size distribution and surface composition were determined by (scanning) transmission electron microscopy using a JEOL JEM-2100F unit operating at an accelerating voltage of $200 \mathrm{kV}$ with resolution to $0.14 \mathrm{~nm}$ and an EDAX Genesis XM 4 system 60. Samples were dispersed in 1-butanol by ultrasonic vibration, deposited on a lacey-carbon/Cu grid (200 Mesh) and dried at $383 \mathrm{~K}$. Up to 300 individual metal particles were counted for each catalyst and the surface area-weighted metal diameter $(d)$ was calculated from:

$$
d=\frac{\sum_{i} n_{i} d_{i}^{3}}{\sum_{i} n_{i} d_{i}^{2}}
$$

where $n_{i}$ is the number of particles of diameter $d_{i}$.

\subsection{Gas phase nitroarene hydrogenation}

2.3.1 Materials. The reactants ( $p$-chloronitobenzene ( $p$-CNB) and $m$-dinitrobenzene $(m$-DNB), Aldrich, $\geq 98 \%)$ and solvent (1-butanol, Riedel-de Haën, $\geq 99.5 \%$ ) were used as supplied, without further purification.

2.3.2 Catalytic system. Catalytic reactions were carried out under atmospheric pressure, in situ immediately after activation, in a fixed bed vertical continuous flow glass reactor (i.d. $=15 \mathrm{~mm}$ ) at $573 \mathrm{~K}$. The reactions were conducted under conditions of 
negligible heat/mass transport limitations. A preheating zone (layer of borosilicate glass beads) ensured that the nitroarene reactant was vaporised and reached reaction temperature before contacting the catalyst. Isothermal conditions $( \pm 1 \mathrm{~K})$ were maintained by thoroughly mixing the catalyst with ground glass $(75 \mu \mathrm{m})$ before insertion into the reactor. Temperature was continuously monitored by a thermocouple inserted in a thermowell within the catalyst bed. The $p$-CNB (or $m$-DNB) reactant was delivered, in a co-current flow of $\mathrm{H}_{2}$, via a glass/ teflon air-tight syringe and a teflon line, using a microprocessor controlled infusion pump (Model $100 \mathrm{kd}$ Scientific) at a fixed calibrated flow rate, with an inlet $-\mathrm{NO}_{2}$ molar flow $\left(F_{-\mathrm{NO}_{2}}\right)$ in the range $1.1 \times 10^{-4}-3.1 \times 10^{-4} \mathrm{~mol} \mathrm{~h}^{-1}$, where the molar metal to inlet $-\mathrm{NO}_{2}$ feed rate ratio spanned the range $1.1 \times 10^{-3}-16.0 \times$ $10^{-3} \mathrm{~h}$. The $\mathrm{H}_{2}$ content was far in excess of the stoichiometric requirement for $-\mathrm{NO}_{2}$ reduction (160-430), the flow rate of which was monitored using a Humonics (Model 520) digital flowmeter; GHSV $=2 \times 10^{4} \mathrm{~h}^{-1}$. In a series of blank tests, passage of $p$-CNB or $m$-DNB in a stream of $\mathrm{H}_{2}$ through the empty reactor or over the supports alone did not result in any detectable conversion.

2.3.3 Analytical method and activity/selectivity evaluation. The reactor effluent was frozen in a liquid nitrogen trap for subsequent analysis using a Perkin-Elmer Auto System XL gas chromatograph equipped with a programmed split/splitless injector and a flame ionization detector, employing a DB-1 $50 \mathrm{~m} \times 0.20 \mathrm{~mm}$ i.d., $0.33 \mu \mathrm{m}$ film thickness capillary column (J\&W Scientific). Repeated catalytic runs with different samples from the same batch of catalyst delivered product compositions that were reproducible to within $\pm 6 \%$ with a carbon balance of $\pm 5 \%$. Catalyst activity is quantified in terms of nitroarene $\left(m\right.$-DNB $\left(X_{m \text {-DNB }}\right)$ or $p$-CNB $\left.\left(X_{p \text {-CNB }}\right)\right)$ fractional conversion

$$
X_{\text {nitroarene }}=\frac{[\text { nitroarene }]_{\text {in }}-[\text { nitroarene }]_{\text {out }}}{[\text { nitroarene }]_{\text {in }}}
$$

where the subscripts "in" and "out" refer to inlet and outlet streams, respectively. Selectivity in terms of (e.g.) $m$-phenylenediamine ( $m$-PDM) from $m$-DNB $\left(S_{m-\mathrm{PDM}}\right)$ is given by

$$
S_{m-\mathrm{PDM}}=\frac{[m-\mathrm{PDM}]_{\mathrm{out}}}{[m-\mathrm{DNB}]_{\mathrm{in}}-[m-\mathrm{DNB}]_{\mathrm{out}}} \times 100
$$

\section{Results and discussion}

\subsection{Catalyst characterisation}

The metal content, specific surface area (SSA), pore volume, $\mathrm{H}_{2}$ uptake/release during TPR/TPD and mean metal particle size for the (mono- and bi-metallic) catalysts used in this study are given in Table 1. The SSA and pore volume of the $\mathrm{Al}_{2} \mathrm{O}_{3}$ support $\left(191 \mathrm{~m}^{2} \mathrm{~g}^{-1} ; 450 \times 10^{-3} \mathrm{~cm}^{3} \mathrm{~g}^{-1}\right)$ are close to values reported for commercial Puralox mesoporous $\gamma-\mathrm{Al}_{2} \mathrm{O}_{3}\left(157 \mathrm{~m}^{2} \mathrm{~g}^{-1} ; 420 \times\right.$ $\left.10^{-3} \mathrm{~cm}^{3} \mathrm{~g}^{-1}\right) .^{25}$ Incorporation of Au and Ni resulted in a measurable decrease in SSA and pore volume that can be ascribed to partial pore filling by the metal(s) or $\mathrm{Al}_{2} \mathrm{O}_{3}$ dissolution during impregnation resulting in pore collapse. ${ }^{26}$ The $\mathrm{TiO}_{2}$ supported systems exhibited similar SSA and pore volumes to the starting support $\left(52 \mathrm{~m}^{2} \mathrm{~g}^{-1}\right.$; $\left.120 \times 10^{-3} \mathrm{~cm}^{3} \mathrm{~g}^{-1}\right)$ that are in accord with Degussa P25 $\left(61 \mathrm{~m}^{2} \mathrm{~g}^{-1}\right.$; $\left.120 \times 10^{-3} \mathrm{~cm}^{3} \mathrm{~g}^{-1}\right) \cdot{ }^{27}$

The TPR profiles generated for $\mathrm{Au} / \mathrm{Al}_{2} \mathrm{O}_{3}-\mathrm{HL}(\mathrm{I}), \mathrm{Au} / \mathrm{Al}_{2} \mathrm{O}_{3}-\mathrm{LL}$ (II) and $\mathrm{Au} / \mathrm{TiO}_{2}$-LL (III) can be compared in Fig. 1. The three samples present a principal $\mathrm{H}_{2}$ consumption peak with an

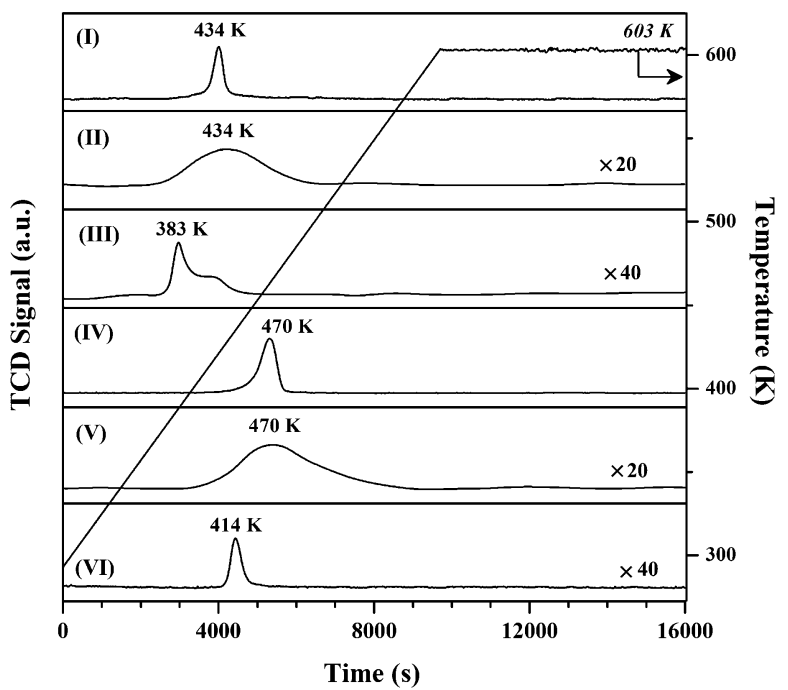

Fig. 1 TPR profiles generated for: (I) $\mathrm{Au} / \mathrm{Al}_{2} \mathrm{O}_{3}-\mathrm{HL}$, (II) $\mathrm{Au} / \mathrm{Al}_{2} \mathrm{O}_{3}-\mathrm{LL}$, (III) $\mathrm{Au} / \mathrm{TiO}_{2}-\mathrm{LL}$, (IV) $(1: 10) \mathrm{Ni}-\mathrm{Au} / \mathrm{Al}_{2} \mathrm{O}_{3}-\mathrm{HL}$, (V) $(1: 10) \mathrm{Ni}-\mathrm{Au} / \mathrm{Al}_{2} \mathrm{O}_{3}-\mathrm{LL}$ and (VI) $(1: 10) \mathrm{Ni}-\mathrm{Au} / \mathrm{TiO}_{2}-\mathrm{LL}$

\begin{tabular}{|c|c|c|c|c|c|c|}
\hline Catalyst $^{a}$ & $\begin{array}{l}\mathrm{SSA}^{b} \\
\left(\mathrm{~m}^{2} \mathrm{~g}^{-1}\right)\end{array}$ & $\begin{array}{l}\text { Pore volume } \times 10^{-3 c} \\
\left(\mathrm{~cm}^{3} \mathrm{~g}^{-1}\right)\end{array}$ & $\begin{array}{l}\text { TPR } \\
T_{\max }(\mathrm{K})\end{array}$ & $\begin{array}{l}\mathrm{TPR} \mathrm{H}_{2}{ }^{d, e} \\
\left(\mu \mathrm{mol} \mathrm{g}_{\text {catalyst }}{ }^{-1}\right)\end{array}$ & $\begin{array}{l}\mathrm{H}_{2} \text { TPD } \\
\left(\mathrm{mmol} \mathrm{mol}_{\mathrm{Au}}{ }^{-1}\right)\end{array}$ & $d^{f}(\mathrm{~nm})$ \\
\hline $\mathrm{Au} / \mathrm{Al}_{2} \mathrm{O}_{3}-\mathrm{HL}$ & 161 & 427 & 434 & $102^{d} / 104^{e}$ & 473 & 9 \\
\hline $\mathrm{Au} / \mathrm{Al}_{2} \mathrm{O}_{3}-\mathrm{LL}$ & 169 & 425 & 434 & $9^{d} / 16^{e}$ & 1101 & 4 \\
\hline $\mathrm{Ni}-\mathrm{Au} / \mathrm{Al}_{2} \mathrm{O}_{3}-\mathrm{LL}$ & 190 & 447 & 470 & $9^{d} / 8^{e}$ & 2471 & 4 \\
\hline
\end{tabular}

Table 1 Physico-chemical characteristics of $\mathrm{Al}_{2} \mathrm{O}_{3}$ and $\mathrm{TiO}_{2}$ supported mono-(Au) and bi-metallic (Ni-Au) catalysts

${ }^{a} \mathrm{Au}$ metal content (mol\%): $\mathrm{LL}=0.1, \mathrm{HL}=1.0,1: 10 \mathrm{Ni}: \mathrm{Au}$ molar ratio in bi-metallics. ${ }^{b}$ Specific surface $\operatorname{area}(\mathrm{SSA}), \mathrm{Al}_{2} \mathrm{O}_{3}=191 \mathrm{~m}^{2} \mathrm{~g}^{-1}, \mathrm{TiO}_{2}=$ $52 \mathrm{~m}^{2} \mathrm{~g}^{-1}$. ${ }^{c}$ Pore volume, $\mathrm{Al}_{2} \mathrm{O}_{3}=450 \times 10^{-3} \mathrm{~cm}^{3} \mathrm{~g}^{-1}$, $\mathrm{TiO}_{2}=120 \times 10^{-3} \mathrm{~cm}^{3} \mathrm{~g}^{-1} \cdot{ }^{d} \mathrm{H}_{2}$ required for the reduction of the metal precursor.

${ }^{e}$ Experimentally determined $\mathrm{H}_{2}$ consumption. ${ }^{f}$ Surface area weighted mean metal particle size from TEM/STEM analysis. 
associated temperature maximum $\left(T_{\max }\right)$ over $383-434 \mathrm{~K}$, which is within the range recorded elsewhere (328-465 $\mathrm{K}$ ) for the activation of $\mathrm{Au} / \mathrm{Al}_{2} \mathrm{O}_{3}$ and $\mathrm{Au} / \mathrm{TiO}_{2}$ and attributed to precursor reduction. ${ }^{28}$ The lower $T_{\max }$ recorded for $\mathrm{Au} / \mathrm{TiO}_{2}-\mathrm{LL}$ (relative to $\left.\mathrm{Au} / \mathrm{Al}_{2} \mathrm{O}_{3}\right)$ is consistent with the literature. ${ }^{29}$ Moreover, Delannoy et $a .^{30}$ have demonstrated (by in situ XAFS and DRIFTS) greater reducibility of cationic gold on $\mathrm{TiO}_{2}$ compared with $\mathrm{Al}_{2} \mathrm{O}_{3}$. Hydrogen consumption during catalyst activation was close to that required for $\mathrm{Au}^{3+}$ reduction (Table 1). Supported bimetallic catalyst preparation involved reductive deposition where Ni with a lower electrochemical potential $(\mathrm{ECP}=-0.27)$ acts to reduce the $\mathrm{Au}$ precursor $\left(\mathrm{HAuCl}_{4}, \mathrm{ECP}=1.00\right) .{ }^{31}$ The TPR profiles generated for $\mathrm{Al}_{2} \mathrm{O}_{3}$ and $\mathrm{TiO}_{2}$ supported $\mathrm{Ni}$ (not shown) exhibited a single broad $\mathrm{H}_{2}$ consumption peak at the final isothermal hold $(723 \mathrm{~K})$ that can be associated with a combined decomposition-reduction of the precursor to metallic nickel, as noted elsewhere. ${ }^{1}$ A single stage reduction was observed for the supported $\mathrm{Ni}-\mathrm{Au}$ systems at a higher $T_{\max }$ (414-470 K) than that recorded for the corresponding monometallic Au catalysts. Modification to the TPR response for $\mathrm{Au}$ containing bimetallic catalysts with respect to monometallic counterparts has been reported and linked to interaction between both metals. ${ }^{32} \mathrm{Pu}$ et $a l .{ }^{33}$ have recently described a stabilisation of $\mathrm{Au}$ species (on activated carbon spheres) with the introduction of Ni by co-impregnation that inhibited reduction, displacing the temperature for $\mathrm{Au}^{\mathrm{III}} \rightarrow \mathrm{Au}^{0}$ (from $583 \mathrm{~K}$ to $588 \mathrm{~K}$ ) and $\mathrm{Au}^{\mathrm{I}} \rightarrow \mathrm{Au}^{0}$ (from $619 \mathrm{~K}$ to $659 \mathrm{~K}$ ) to higher values.

Gold particle size, from TEM analysis (Fig. 2 and 3 and Table 1), is dependent on metal loading and the nature of the support. The particle size in $\mathrm{Au} / \mathrm{Al}_{2} \mathrm{O}_{3}-\mathrm{HL}$ was in the range 1-20 nm (Fig. 3(I)) with a surface area weighted mean diameter of $9 \mathrm{~nm}$. The lower $\mathrm{Au}$ loaded sample $\left(\mathrm{Au} / \mathrm{Al}_{2} \mathrm{O}_{3}-\mathrm{LL}\right)$ exhibited a narrower size distribution (1-8 nm, Fig. 3(II)) and smaller mean (4 nm). This effect is consistent with literature that has shown wider size range and the formation of larger nanoparticles with increasing $\mathrm{Au}$ content. ${ }^{34}$ This can be linked to mobility of the chloride precursor, resulting in $\mathrm{Au}$ agglomeration during thermal treatment. ${ }^{35}$ Enhanced Au dispersion on $\mathrm{TiO}_{2}$ (Fig. 3(III)) is a consequence of a difference in metal/support interaction relative to $\mathrm{Au} / \mathrm{Al}_{2} \mathrm{O}_{3} \cdot{ }^{36}$ Loss of lattice oxygen with the formation of surface vacancies is a feature of thermal treatment in $\mathrm{H}_{2}$ for reducible oxides such as $\mathrm{TiO}_{2}$ at $T \geq 573 \mathrm{~K}^{37}$ These surface defects act as Au nucleation sites with electronic interactions that limit particle growth, leading to enhanced dispersion. ${ }^{38,39}$

Representative (S)TEM images of Ni-Au/ $\mathrm{Al}_{2} \mathrm{O}_{3}-\mathrm{HL}$ (I), Ni-Au/ $\mathrm{Al}_{2} \mathrm{O}_{3}$-LL (III) and Ni-Au/TiO $-\mathrm{LL}$ (IV) can be compared in Fig. 4 . The metal size range in $\mathrm{Ni}-\mathrm{Au} / \mathrm{Al}_{2} \mathrm{O}_{3}-\mathrm{HL}$ (1-20 nm) coincided with $\mathrm{Au} / \mathrm{Al}_{2} \mathrm{O}_{3}-\mathrm{HL}$ and there was no obvious alteration due the inclusion of $\mathrm{Ni}$. This response extended to $\mathrm{Ni}-\mathrm{Au} / \mathrm{Al}_{2} \mathrm{O}_{3}-\mathrm{LL}$ and $\mathrm{Ni}-\mathrm{Au} / \mathrm{TiO}_{2}-\mathrm{LL}$ with an equivalent mean metal size relative to the monometallic system (see Table 1). This can be attributed to the low Ni content in the bimetallic samples. An unchanged metal particle size has been reported previously for $\mathrm{TiO}_{2}$ supported $\mathrm{Au}$ and Pt-Au with low Pt content (0.01-0.03 wt\%). ${ }^{9}$ EDX mapping (see representative analysis for $\mathrm{Ni}-\mathrm{Au} / \mathrm{Al}_{2} \mathrm{O}_{3}-\mathrm{HL}$ in Fig. 4(II)) demonstrated that individual particles contained both $\mathrm{Au}$ and $\mathrm{Ni}$ in proportions close to the bulk value $(\mathrm{Au} / \mathrm{Ni}=10)$.
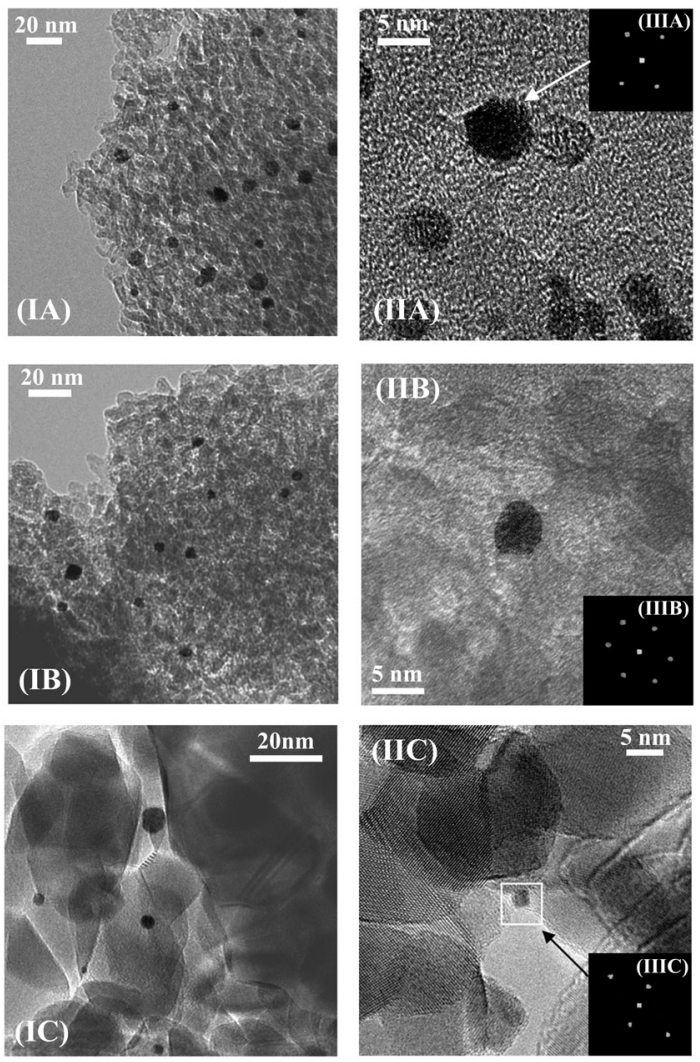

Fig. 2 Representative (I) medium and (II) high resolution TEM images with (III) associated diffractogram pattern of an isolated single Au nanoparticle in (A) $\mathrm{Au} / \mathrm{Al}_{2} \mathrm{O}_{3}-\mathrm{HL}$, (B) $\mathrm{Au} / \mathrm{Al}_{2} \mathrm{O}_{3}-\mathrm{LL}$ and (C) $\mathrm{Au} / \mathrm{TiO} \mathrm{O}_{2}-\mathrm{LL}$.

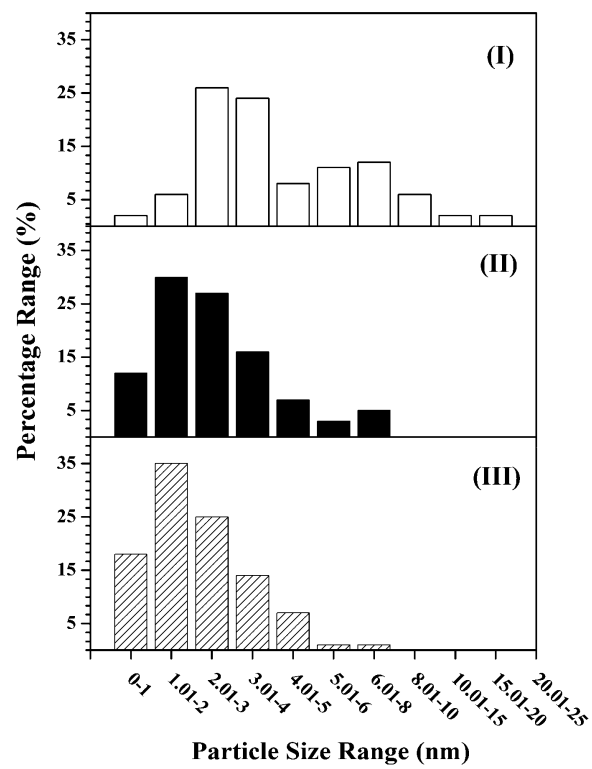

Fig. 3 Gold particle size distributions associated with (I) $\mathrm{Au} / \mathrm{Al}_{2} \mathrm{O}_{3}-\mathrm{HL}$ (open bars), (II) $\mathrm{Au} / \mathrm{Al}_{2} \mathrm{O}_{3}-\mathrm{LL}$ (solid bars) and (III) $\mathrm{Au} / \mathrm{TiO} \mathrm{O}_{2}-\mathrm{LL}$ (hatched bars).

EDX analysis cannot establish unequivocally the exact nature of $\mathrm{Ni}-\mathrm{Au}$ interaction or rule out the occurrence of bimetallic clusters ${ }^{40}$ or surface alloy. ${ }^{41}$ Both possibilities have been suggested 

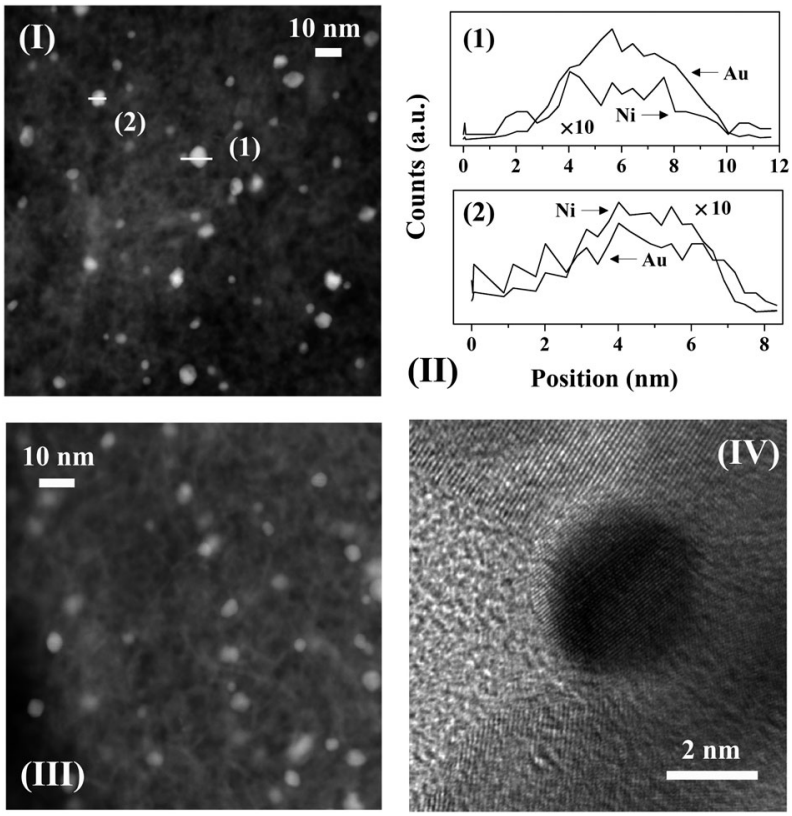

Fig. 4 Representative TEM/STEM images of (I) $\mathrm{Ni}-\mathrm{Au} / \mathrm{Al}_{2} \mathrm{O}_{3}-\mathrm{HL}$ showing (1) $12 \mathrm{~nm}$ and (2) $8 \mathrm{~nm}$ segments across individual metal particles subjected to (II) EDX mapping with the associated Ni (counts $\times 10$ ) and Au distribution, (III) $\mathrm{Ni}-\mathrm{Au} / \mathrm{Al}_{2} \mathrm{O}_{3}-\mathrm{LL}$ and (IV) $\mathrm{Ni}-\mathrm{Au} / \mathrm{TiO}_{2}-\mathrm{LL}$.

for $\mathrm{Ni}-\mathrm{Au}$ catalysts prepared in an analogous manner and with a similar metal dispersion to that in this study. ${ }^{16,42,43}$ Deghedi and co-workers ${ }^{42}$ proposed the formation of $\mathrm{Ni}$ particles covered with $\mathrm{Au}$ adatoms (on the basis of EXAFS and TEM-EDX measurements) for $\mathrm{Ni}-\mathrm{Au} / \mathrm{SiO}_{2}$ synthesised by redox deposition that contained metal ensembles of $5.1 \mathrm{~nm}$. Maniecki and co-workers ${ }^{44}$ reported an alloy phase (on the basis of XRD) for $\mathrm{Ni}-\mathrm{Au} / \mathrm{Al}_{2} \mathrm{O}_{3}$ prepared by co-impregnation (with $\mathrm{Ni}\left(\mathrm{NO}_{3}\right)_{2}$ and $\mathrm{HAuCl}_{4}$ ) and reduction in $\mathrm{H}_{2}$. Surface alloy formation was suggested by EXAFS/XANES for $\mathrm{Au}-\mathrm{Ni} / \mathrm{MgAlO}_{4}(10.1 \mathrm{~nm})$ prepared by redox deposition. ${ }^{16}$ Molenbroek and Nørskov ${ }^{43}$ also demonstrated the occurrence of a surface alloy in $\mathrm{Ni}-\mathrm{Au} / \mathrm{SiO}_{2}(2.5-6.0 \mathrm{~nm})$ and $\mathrm{Ni}-\mathrm{Au} / \mathrm{MgAl}_{2} \mathrm{O}_{4}$ (3.0-15.0 nm) by Monte Carlo simulations, which was experimentally verified by EXAFS, TEM and in situ XRD.

The hydrogenation of nitroarenes is enhanced by contributions due to spillover hydrogen. ${ }^{19,36}$ The generation of spillover species involves dissociative adsorption of $\mathrm{H}_{2}$ on a (donor) supported metal site with migration of the atomic hydrogen generated to the (acceptor) support. ${ }^{45}$ Hydrogen TPD is a practical approach that can serve to quantify the degree of spillover. Ambient temperature $\mathrm{H}_{2}$ chemisorption following TPR on all the catalysts was low ( $\leq 15 \mathrm{mmol} \mathrm{mol}_{\mathrm{Au}}{ }^{-1}$ ) and close to the detection limits. Low uptake on supported Au has been demonstrated elsewhere and attributed to the filled d-band and high activation energy barrier for dissociative adsorption. ${ }^{6,46}$ There was no measurable difference in ambient temperature $\mathrm{H}_{2}$ uptake on the bimetallics, which may be due to the low Ni content. The $\mathrm{H}_{2}$ TPD profiles are presented in Fig. 5. In all cases, the profiles show $\mathrm{H}_{2}$ release with maxima at $T \geq 770 \mathrm{~K}$ where the total amount desorbed (per $\mathrm{mol}_{\mathrm{Au}}$, Table 1) was appreciably greater (by two orders of magnitude) than that taken up in the chemisorption step. This response

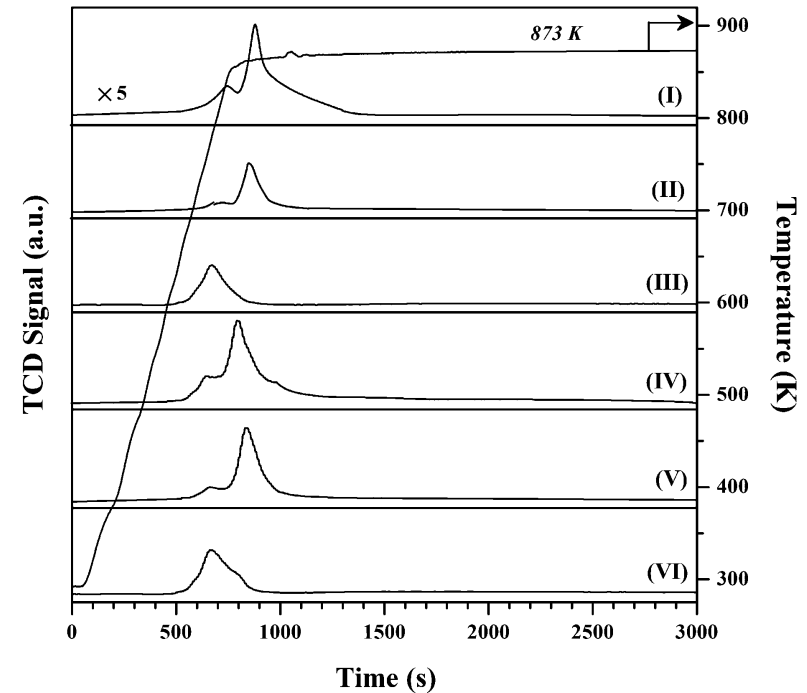

Fig. 5 Hydrogen TPD profiles generated for: (I) $\mathrm{Au} / \mathrm{Al}_{2} \mathrm{O}_{3}-\mathrm{HL}$, (II) $\mathrm{Au} / \mathrm{Al}_{2} \mathrm{O}_{3}-\mathrm{LL}$, (III) $\mathrm{Au} / \mathrm{TiO}_{2}-\mathrm{LL}$, (IV) $(1: 10) \mathrm{Ni}-\mathrm{Au} / \mathrm{Al}_{2} \mathrm{O}_{3}-\mathrm{HL}$, (V) (1:10) $\mathrm{Ni}-\mathrm{Au} / \mathrm{Al}_{2} \mathrm{O}_{3}-\mathrm{LL}$ and (VI) $(1: 10) \mathrm{Ni}-\mathrm{Au} / \mathrm{TiO}_{2}-\mathrm{LL}$.

suggests the release of spillover hydrogen generated during catalyst activation by TPR. ${ }^{45}$ The shift in the TPD peak for $\mathrm{TiO}_{2}$ systems to a lower temperature (by up to a $100 \mathrm{~K}$ ) is indicative of a less energetically demanding desorption of $\mathrm{H}_{2}$. This is consistent with literature ${ }^{47,48}$ that has reported a down-shift (by ca. 60-70 K) in the $\mathrm{H}_{2}$-TPD peak for $\mathrm{Ni} / \mathrm{TiO}_{2}$ and $\mathrm{Pd}-\mathrm{Au} / \mathrm{Al}_{2} \mathrm{O}_{3}$ $\mathrm{TiO}_{2}$ compared with $\mathrm{Ni} / \mathrm{Al}_{2} \mathrm{O}_{3}$ and $\mathrm{Pd}-\mathrm{Au} / \mathrm{Al}_{2} \mathrm{O}_{3}$, respectively. Taking the three monometallic Au catalysts presented in Fig. 5, $\mathrm{H}_{2}$ desorbed (Table 1) increased in the order: $\mathrm{Au} / \mathrm{Al}_{2} \mathrm{O}_{3}-\mathrm{HL}(\mathrm{I})<$ $\mathrm{Au} / \mathrm{Al}_{2} \mathrm{O}_{3}$-LL (II) $<\mathrm{Au} / \mathrm{TiO}_{2}$-LL (III) where the values obtained are close (54-932 $\mathrm{mmol} \mathrm{mol}_{\mathrm{Au}}{ }^{-1}$ ) to those reported elsewhere for $\mathrm{Au}$ with similar metal size $(3-5 \mathrm{~nm})$ supported on $\mathrm{Fe}_{2} \mathrm{O}_{3} \cdot{ }^{36}$ This sequence reflects that of decreasing mean Au nanoparticle size (Table 1). There is evidence in the literature ${ }^{23}$ that metal size is a crucial variable controlling spillover where a greater (donor) surface area for smaller metal nanoparticles extends the donor/acceptor interface and facilitates spillover transfer. The profiles generated for the bimetallic Ni-Au catalysts (Fig. 5, profiles IV-VI) reveals a significant increase in $\mathrm{H}_{2}$ desorbed relative to Au samples with the same loading (see Table 1). This suggests a surface $\mathrm{Ni} / \mathrm{Au}$ synergism that impacts on $\mathrm{H}_{2}$ adsorption/ desorption dynamics. The existing literature on Au containing bimetallics for hydrogenation applications has been from the perspective of $\mathrm{Au}$ as a diluent with low $\mathrm{H}_{2}$ uptake capacity and a resultant decrease in surface hydrogen associated with the bimetallic. ${ }^{49}$ As a result, there is no directly comparable $\mathrm{H}_{2}$ TPD analysis for supported bimetallic Au-containing systems where the second metal was present in small amounts. We should flag the work of Wojcieszak et al. ${ }^{50}$ who observed an increase in $\mathrm{H}_{2}$ released $\left(0.22 \rightarrow 0.38 \mathrm{~mol} \mathrm{~g}^{-1}\right)$ during $\mathrm{TPD}$ of $\mathrm{Ni}-\mathrm{Ag} / \mathrm{SiO}_{2}$ with increasing $\mathrm{Ni}$ content $(0.50 \rightarrow 0.75 \mathrm{wt} \%)$. It is important to note that $\mathrm{Ni}-\mathrm{Au} / \mathrm{Al}_{2} \mathrm{O}_{3}$ - $\mathrm{HL}$ with lower metal dispersion showed significantly greater $\mathrm{H}_{2}$ desorption (Table 1) relative to $\mathrm{Ni}-\mathrm{Au}$ / $\mathrm{Al}_{2} \mathrm{O}_{3}$-LL. STEM-EDX analyses have demonstrated the presence 
of both metals on individual nanoparticles. The formation of bimetallic nano-crystals (i.e. Au decorating Ni nanoparticles) has been demonstrated (EXAFS and TEM-EDS) for Ni-Au bimetallics prepared and activated using a similar methodology. ${ }^{42}$ It is known that $\mathrm{H}_{2}$ interaction is distinct for monometallic, bimetallic and alloy nanoparticles. ${ }^{51,52}$ The greater Ni loading in $\mathrm{Ni}-\mathrm{Au} / \mathrm{Al}_{2} \mathrm{O}_{3}-\mathrm{HL}(0.1 \mathrm{~mol} \%$ vs. $0.01 \mathrm{~mol} \%)$ must facilitate $\mathrm{H}_{2}$ dissociative adsorption and spillover during TPR, which is reflected in greater $\mathrm{H}_{2}$ release during TPD. In the case of the low loading bimetallics, $\mathrm{H}_{2}$ desorption from $\mathrm{Ni}-\mathrm{Au} / \mathrm{Al}_{2} \mathrm{O}_{3}-\mathrm{LL}$ exceeded $\mathrm{Ni}-\mathrm{Au} / \mathrm{TiO}_{2}$-LL (Table 1 ). This can be tentatively linked to modifications induced by the support that impact on $\mathrm{H}_{2}$ uptake on the bimetallic phase. Likewise, Gu et al. ${ }^{47}$ observed a greater $\mathrm{H}_{2}$ TPD from $\mathrm{Pd}-\mathrm{Au} / \mathrm{Al}_{2} \mathrm{O}_{3}$ relative to $\mathrm{Pd}-\mathrm{Au} / \mathrm{Al}_{2} \mathrm{O}_{3}-\mathrm{TiO}_{2}$. The characterisation analysis has established the formation of nanoscale (mean $=3-9 \mathrm{~nm}$ ) Au particles in the monometallics with greater surface hydrogen for catalysts with increasing metal dispersion. TPR measurements suggest interaction of Ni with $\mathrm{Au}$ in the bimetallics. STEM-EDX analysis has demonstrated the presence of $\mathrm{Au}$ and $\mathrm{Ni}$ in individual nanoparticles and the TPD results are consistent with increased spillover resulting from $\mathrm{Au} / \mathrm{Ni}$ synergy that increases the available surface hydrogen.

\subsection{Gas phase nitroarene hydrogenation}

The hydrogenation of $p$-CNB and $m$-DNB over all the catalysts delivered time-invariant conversions (not shown) and exclusive nitro-group reduction with no evidence of hydrodechlorination, hydrodenitrogenation or aromatic ring reduction. This combined stability/selectivity is important in terms of the viable application of $\mathrm{Au}$ catalyst formulations in the production of functionalised anilines. Catalyst deactivation in hydrogenation (of naphthalene, ${ }^{53} 1,3$-butadiene ${ }^{54}$ and acetylene ${ }^{55,56}$ ) has been reported for $\mathrm{Au}$ supported on $\mathrm{Al}_{2} \mathrm{O}_{3}{ }^{53,54,57}$ and $\mathrm{TiO}_{2}{ }^{55,56}$ and ascribed to metal sintering ${ }^{54,55}$ and coking. ${ }^{55-57}$ Moreover, temporal loss of activity in the gas phase hydrogenation of nitroarenes over $\mathrm{Pd} / \mathrm{Al}_{2} \mathrm{O}_{3}$ has been observed and linked to coke formation. ${ }^{58,59}$

The applicability of pseudo-first order kinetics for the gas phase hydrogenation of $p$-CNB ${ }^{1,60}$ and $m-\mathrm{DNB}^{36}$ has been established elsewhere. The extracted specific (per $\mathrm{mol}_{\mathrm{Au}}$ ) pseudofirst order rate constants $(k)$ are given in Table 2 . The promoting effect of Ni is demonstrated by the significantly increased hydrogenation rate when compared with the monometallic Au catalysts with the same loading. Under the same reaction conditions, $\mathrm{Ni} / \mathrm{Al}_{2} \mathrm{O}_{3}$ and $\mathrm{Ni} / \mathrm{TiO}_{2}$ delivered negligible activity. Duan and co-workers ${ }^{61}$ using unsupported nano-crystals reported increased rate ( $\mathrm{mol}_{\text {product }} \mathrm{mol}_{\text {metal }}{ }^{-1}$ ) in the high pressure (40 atm) liquid phase hydrogenation of phenol $(283 \rightarrow 363)$ and benzene $(164 \rightarrow$ 261) over $\mathrm{Ni}-\mathrm{Rh}$ relative to $\mathrm{Rh}$, which was attributed to the bimetallic character of the nanoparticles (based on HRTEM-EDX and XRD) and possible modifications in active site electron density. Lu et al. ${ }^{62,63}$ recorded higher activity in the liquid phase hydrogenation of a series of $p$-substituted nitro-derivates over $\mathrm{Ni}-\mathrm{Pd}$ colloids, ascribed to the formation of a Ni enriched alloy (from XRD, EXAFS, XPS). The elevated rate observed in this study can be linked to surface available reactive hydrogen as shown in Fig. 6 where $\mathrm{H}_{2}$-TPD is related to the rate constant.
Table 2 Catalysis results: pseudo-first order rate constant $(k)$ and product distribution (at $X \sim 0.07$ ) in the hydrogenation of $p$-CNB and $m$-DNB over $\mathrm{Al}_{2} \mathrm{O}_{3}$ and $\mathrm{TiO}_{2}$ supported monometallic ( $\mathrm{Au}$ ) and bimetallic (Ni-Au; $1: 10$ molar ratio) catalysts; reaction conditions: $P=1 \mathrm{~atm}, T=573 \mathrm{~K}$

\begin{tabular}{|c|c|c|}
\hline \multirow[b]{2}{*}{ Catalyst } & $p$-CNB & $m$-DNB \\
\hline & $k^{a}$ Product(s) $\left(S_{\text {product }}(\%)\right)$ & $k^{a}$ Product(s) $\left(S_{\text {product }}(\%)\right)$ \\
\hline $\mathrm{Au} / \mathrm{Al}_{2} \mathrm{O}_{3}-\mathrm{HL}$ & $4 p$-CAN (100) & 6 m-NAN (100) \\
\hline $\mathrm{Ni}-\mathrm{Au} / \mathrm{Al}_{2} \mathrm{O}_{3}^{-}$ & $24 p$-CAN $(100)$ & $40 m$-NAN $(60)$ \\
\hline $\mathrm{HL}$ & & $m$-PDM (40) \\
\hline $\mathrm{Au} / \mathrm{Al}_{2} \mathrm{O}_{3}-\mathrm{LL}$ & $12 p$-CAN (100) & 16 m-NAN (100) \\
\hline $\mathrm{Ni}-\mathrm{Au} / \mathrm{Al}_{2} \mathrm{O}_{3}-\mathrm{LL}$ & $21 p$-CAN $(100)$ & 35 m-NAN (100) \\
\hline $\mathrm{Au} / \mathrm{TiO}_{2}-\mathrm{LL}$ & $18 p$-CAN (100) & $22 m$-NAN (100) \\
\hline $\mathrm{Ni}-\mathrm{Au} / \mathrm{TiO}_{2}-\mathrm{LL}$ & $22 p$-CAN (100) & 25 m-NAN (80) \\
\hline & & $m$-PDM (20) \\
\hline \multicolumn{3}{|c|}{${ }^{a} \mathrm{~mol}_{-\mathrm{NO}_{2}} \mathrm{~mol}_{\mathrm{Au}}{ }^{-1} \mathrm{~h}^{-1}}$. \\
\hline
\end{tabular}

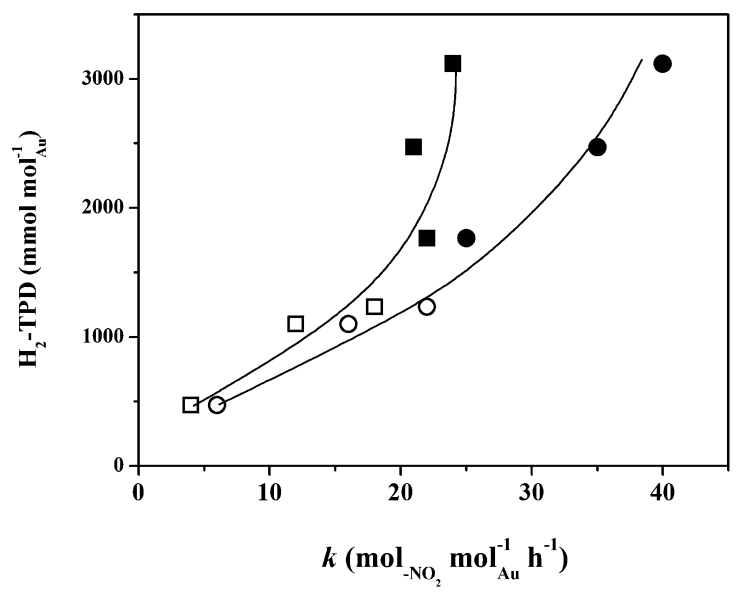

Fig. 6 Variation in hydrogen TPD $\left(\mathrm{H}_{2}-\mathrm{TPD}\right)$ with pseudo-first order rate constant $(k)$ in the hydrogenation of $p-\operatorname{CNB}(\square, \mathbf{\square})$ and $m-\operatorname{DNB}(\bigcirc, \bullet$ over supported $\mathrm{Au}$ (open symbols) and $\mathrm{Ni}-\mathrm{Au}$ (solid symbols) catalysts.

The increase in surface hydrogen that results from incorporation of Ni with Au was accompanied by a higher hydrogenation rate. Moreover, reaction of $m$-DNB uniformly generated greater rates, a result that can be attributed to the activating effect of the second $-\mathrm{NO}_{2}$ group, which is consistent with a nucleophilic mechanism, as demonstrated previously. ${ }^{64}$

Reaction selectivity is compared at the same degree of conversion in Table 2. $p$-CNB was converted solely to the target ( $p$-chloroaniline) $p$-CAN over all the catalysts, which is consistent with reaction exclusivity in continuous gas phase $p$-CNB $\rightarrow$ $p$-CAN over oxide supported Au. ${ }^{49}$ In contrast, nitrobenzene, ${ }^{1}$ aniline $^{1}$ and benzene ${ }^{65}$ have been observed in the gas phase hydrogenation of $\mathrm{CNB}$ over $\mathrm{Ru},{ }^{65}$ and $\mathrm{Pd}^{1}$ catalysts. Variations in product distribution are, however, evident in the hydrogenation of $m$-DNB and sensitive to the nature of the catalyst. Full selectivity to partially reduced ( $m$-nitroaniline) $m$-NAN was obtained over monometallic Au systems. In batch liquid phase operation, high pressures (26-34 atm) have been deemed essential to achieve high selectivity (84-98\%) to $m$-NAN. ${ }^{4866}$ Preferential $-\mathrm{NO}_{2}$ activation on oxide supported $\mathrm{Au}$ in the presence of other 
reactive ( $\mathrm{C}=\mathrm{C}$, carbonyl, amide and ester) functional groups has been demonstrated by FTIR analysis. ${ }^{67}$ The incorporation of $\mathrm{Ni}$ at low loading $\left(\mathrm{Ni}-\mathrm{Au} / \mathrm{Al}_{2} \mathrm{O}_{3}-\mathrm{LL}\right)$ served to increase rate while retaining $100 \%$ selective to $m$-NAN. Deghedi et al. ${ }^{42}$ reported that the combination of $\mathrm{Au}$ and $\mathrm{Ni}$ on $\mathrm{SiO}_{2}(\mathrm{Ni}: \mathrm{Au}$ molar ratio $=4: 1$ ) lowered the rate of $\mathrm{C}=\mathrm{C}$ bond and aromatic ring hydrogenation relative to $\mathrm{Ni}$ in the conversion of styrene, which was accounted for in terms of geometric and electronic effects. At higher loadings ( $\left.\mathrm{Ni}-\mathrm{Au} / \mathrm{Al}_{2} \mathrm{O}_{3}-\mathrm{HL}\right)$ complete hydrogenation to $m$-PDM was observed, which is a characteristic of catalysis by $\mathrm{Ni}^{18,19}$ This may be a consequence of increased surface reactive hydrogen which facilitates reduction of both $-\mathrm{NO}_{2}$ substituents. Alternatively, $m$-DNB activation on $\mathrm{Ni}-\mathrm{Au} / \mathrm{Al}_{2} \mathrm{O}_{3}-\mathrm{HL}$ may be distinct from $\mathrm{Ni}-\mathrm{Au} / \mathrm{Al}_{2} \mathrm{O}_{3}$-LL with a planar adsorption on the former through the aromatic ring, resulting in the formation of a resonance structure with two positive localised charges where both $-\mathrm{NO}_{2}$ groups are activated for nucleophilic attack. It is known that substituted aromatics interact with supported Ni catalysts via the $\pi$ electron-delocalised aromatic ring. ${ }^{68}$ Lonergan et al. ${ }^{69}$ have observed $n$-butane selectivity effects in 1,3-butadiene hydrogenation over Ni-Pt $/ \mathrm{Al}_{2} \mathrm{O}_{3}$ with increasing Ni content $(1: 3 \rightarrow 1: 10)$. The formation of $m$-PDM was also promoted over $\mathrm{Ni}-\mathrm{Au} / \mathrm{TiO}_{2}-\mathrm{LL}$, which suggests a support effect in terms of $m$-DNB adsorption/activation that acts in tandem with differences in available reactive hydrogen. Wang et al. ${ }^{70}$ reported a modified catalytic response in the hydrogenation of 1,3-budatiene for $\mathrm{Pt}-\mathrm{Ni}$ on $\mathrm{Al}_{2} \mathrm{O}_{3}$ and $\mathrm{TiO}_{2}$. DFT calculations revealed stronger metal interaction with $\mathrm{Al}_{2} \mathrm{O}_{3}$ (binding energy ca. $\left.-50 \mathrm{kcal} \mathrm{mol}^{-1}\right)$ than $\mathrm{TiO}_{2}\left(-17 \mathrm{kcal} \mathrm{mol}^{-1}\right)$ with a preferential $\mathrm{Ni}-\mathrm{Al}_{2} \mathrm{O}_{3}$ interaction at the metal-support interface leading to a Pt-terminated bimetallic configuration. A weaker $\mathrm{Ni}$ interaction in the case of the $\mathrm{TiO}_{2}$ carrier can then result in some segregation of the Ni component to the nanoparticle surface.

\section{Conclusions}

Oxide $\left(\mathrm{Al}_{2} \mathrm{O}_{3}\right.$ and $\left.\mathrm{TiO}_{2}\right)$ supported $\mathrm{Au}$ (1 and $0.1 \mathrm{~mol} \%$ ) prepared by impregnation with subsequent activation generated nano-scale metal particles of mean size 3-9 $\mathrm{nm}$. A decrease in $\mathrm{Au}$ size was accompanied by increased surface hydrogen (from TPD analysis) with higher specific chemoselective hydrogenation rate in the conversion of $p$-CNB $\rightarrow p$-CAN and $m$-DNB $\rightarrow$ $m$-NAN. Supported bimetallic synthesis by reductive deposition of $\mathrm{Au}$ on $\mathrm{Ni}$ (where $\mathrm{Au} / \mathrm{Ni}=10$ ) generated an equivalent particle size at the same Au loading but elevates the available surface hydrogen with a significant increase in $-\mathrm{NO}_{2}$ group reduction rate. TPR analysis suggests $\mathrm{Ni}-\mathrm{Au}$ interaction where (S)TEM-EDX mapping across isolated single particles has established $\mathrm{Au}$ and $\mathrm{Ni}$ in close proximity with a surface $\mathrm{Au} / \mathrm{Ni}$ that coincided with the bulk value. Reaction of $p$-CNB over the bimetallics delivered full selectivity to $p$-CAN. Conversion of $m$-DNB was fully selective to $m$-NAN over monometallic $\mathrm{Au}$ and $\mathrm{Ni}-\mathrm{Au} / \mathrm{Al}_{2} \mathrm{O}_{3}$-LL. The hydrogenation of both $-\mathrm{NO}_{2}$ substituents (to $m$-PDM) was promoted over $\mathrm{Ni}-\mathrm{Au} / \mathrm{Al}_{2} \mathrm{O}_{3}-\mathrm{HL}$ and $\mathrm{Ni}-\mathrm{Au} / \mathrm{TiO}_{2}-\mathrm{LL}$. This is attributed to the higher Ni loading that elevated the surface supply of hydrogen and possible electronic/geometric modifications induced by the support that impact on the $m$-DNB adsorption/activation. We have demonstrated $\mathrm{Au} / \mathrm{Ni}$ synergy that serves to enhance $-\mathrm{NO}_{2}$ reduction rate.

\section{Acknowledgements}

The authors are grateful to Dr Santiago Gómez-Quero, Dr Noémie Perret and Pedro Benavente Donayre for their contribution to the work.

\section{References}

1 F. Cárdenas-Lizana, S. Gómez-Quero, C. Amorim and M. A. Keane, Appl. Catal., A, 2014, 473, 41.

2 A. Yarulin, I. Yuranov, F. Cárdenas-Lizana, D. T. L. Alexander and L. Kiwi-Minsker, Appl. Catal., A, 2014, 478, 186.

3 G. Yuan, C. Louis, L. Delannoy and M. A. Keane, J. Catal., 2007, 247, 256.

4 A. Villa, D. Wang, D. S. Su and L. Prati, Catal. Sci. Technol., 2015, 5, 55.

5 F. Cárdenas-Lizana and M. A. Keane, in Gold Catalysis: Preparation, Characterization and Applications in the Gas and Liquid Phase, ed. L. Prati and A. Villa, Pan Stanford Publishing, Singapore, 2014.

6 C. Kartusch and J. A. van Bokhoven, Gold Bull., 2009, 42, 343.

7 G. C. Bond, Platinum Met. Rev., 2007, 51, 63.

8 F. Cárdenas-Lizana, S. Gómez-Quero, A. Hugon, L. Delannoy, C. Louis and M. A. Keane, J. Catal., 2009, 262, 235.

9 D. P. He, X. D. Jiao, P. Jiang, J. Wang and B. Q. Xu, Green Chem., 2012, 14, 111.

10 C. Louis, in Environmental Catalysis over Gold-based Materials, ed. G. Avgouropoulos and T. Tabakova, The Royal Society of Chemistry, Cambridge, 2013.

11 F. Besenbacher, I. Chorkendorff, B. S. Clausen, B. Hammer, A. M. Molenbroek, J. K. Nørskov and I. Stensgaard, Science, 1998, 279, 1913.

12 L. P. Nielsen, F. Besenbacher, I. Stensgaard, E. Laegsgaard, C. Engdahl, P. Stoltze, K. W. Jacobsen and J. K. Nørskov, Phys. Rev. Lett., 1993, 71, 754.

13 A. G. Rybkin, D. Y. Usachev, A. Y. Varykhalov, A. M. Shikin and V. K. Adamchuk, Phys. Solid State, 2007, 49, 984.

14 A. V. Naumkin and A. Y. Vasil'kov, Russ. Chem. Bull., 2013, $62,2559$.

15 H. Nishikawa, D. Kawamoto, Y. Yamamoto, T. Ishida, H. Ohashi, T. Akita, T. Honma, H. Oji, Y. Kobayashi, A. Hamasaki, T. Yokoyama and M. Tokunaga, J. Catal., 2013, 307, 254.

16 Y.-H. Chin, D. L. King, H.-S. Roh, Y. Wang and S. M. Heald, J. Catal., 2006, 244, 153.

17 J. Zhang, H. Asakura, J. van Rijn, J. Yang, P. Duchesne, B. Zhang, X. Chen, P. Zhang, M. Saeys and N. Yan, Green Chem., 2014, 16, 2432.

18 F. Cárdenas-Lizana, S. Gómez-Quero, G. Jacobs, Y. Ji, B. H. Davis, L. Kiwi-Minsker and M. A. Keane, J. Phys. Chem. C, 2012, 116, 11166. 
19 F. Cárdenas-Lizana, S. Gómez-Quero, C. J. Baddeley and M. A. Keane, Appl. Catal., A, 2010, 387, 155.

20 F. Cárdenas-Lizana, S. Gómez-Quero and M. A. Keane, Appl. Catal., A, 2008, 334, 199.

21 W.-S. Lee, B.-Z. Wan, C.-N. Kuo, W.-C. Lee and S. Cheng, Catal. Commun., 2007, 8, 1604.

22 R. Zanella and C. Louis, Catal. Today, 2005, 107-108, 768.

23 C. Amorim and M. A. Keane, J. Colloid Interface Sci., 2008, 322, 196.

24 J. Chen, X. Liu and F. Zhang, Chem. Eng. J., 2015, 259, 43.

25 E. Kok, N. Cant, D. Trimm and J. Scott, Catal. Today, 2011, 178, 79.

26 J. W. Bae, Y.-J. Lee, J.-Y. Park and K.-W. Jun, Energy Fuels, 2008, 22, 2885.

27 T. R. Jagannath, PhD dissertation, Saurashtra University, 2005.

28 Y.-J. Chen and C.-T. Yeh, J. Catal., 2001, 200, 59.

29 S. Y. Liu and S. M. Yang, Appl. Catal., A, 2008, 334, 92.

30 L. Delannoy, N. Weiher, N. Tsapatsaris, A. M. Beesley, L. Nchari, S. L. M. Schroeder and C. Louis, Top. Catal., 2007, 44, 263.

31 D. R. Lide, Handbook of Chemistry and Physical Properties, Taylor Francis, Boca Raton, 88th edn, 2007-2008.

32 F.-W. Chang, L. S. Roselin and T.-C. Ou, Appl. Catal., A, 2008, 334, 147.

33 Y. Pu, J. Zhang, X. Wang, H. Zhang, L. Yu, Y. Dong and W. Li, Catal. Sci. Technol., 2014, 4, 4426.

34 F. Cárdenas-Lizana, S. Gómez-Quero, H. Idriss and M. A. Keane, J. Catal., 2009, 268, 223.

35 A. Schulz and M. Hargittai, Chem. - Eur. J., 2001, 7, 3657.

36 F. Cárdenas-Lizana, S. Gómez-Quero, N. Perret and M. A. Keane, Catal. Sci. Technol., 2011, 1, 652.

37 P. Claus, A. Brückner, C. Mohr and H. Hofmeister, J. Am. Chem. Soc., 2000, 122, 11430.

38 N. Lopez, J. K. Nørskov, T. V. W. Janssens, A. Carlsson, A. Puig-Molina, B. S. Clausen and J.-D. Grunwaldt, J. Catal., 2004, 225, 86.

39 P. V. Kamat, J. Phys. Chem. C, 2008, 112, 18737.

40 D. Chen, J. Li, C. Shi, X. Du, N. Zhao, J. Sheng and S. Liu, Chem. Mater., 2007, 19, 3399.

41 S.-H. Zhou, Z. Ma, H.-F. Yin, Z.-L. Wu, B. Eichhorn, S. H. Overbury and S. Dai, J. Phys. Chem. C, 2009, 113, 5758.

42 L. Deghedi, J.-M. Basset, G. Bergeret, J.-P. Candy, M. C. Valero, J.-A. Dalmon, A. de Mallmann, A.-C. Dubreuil and L. Fischer, in 10th International Symposium "Scientific Bases for the Preparation of Heterogeneous Catalysts", ed. E. M. Gaigneaux, M. Devillers, S. Hermans, P. Jacobs, J. Martens and P. Ruiz, Elsevier, Louvain-la-Newuve, 2010, vol. 175, p. 617.
43 A. M. Molenbroek and J. K. Nørskov, J. Phys. Chem. B, 2001, 105, 5450.

44 T. P. Maniecki, K. Bawolak, D. Gebauer, P. Mierczynski and W. K. Jozwiak, Kinet. Catal., 2009, 50, 138.

45 W. C. Conner and J. L. Falconer, Chem. Rev., 1995, 95, 759. 46 J. Harris, Surf. Sci., 1989, 221, 335.

47 Z. Gu, L. Luo and M. Teng, Indian J. Chem., 2007, 46A, 742. 48 Y. X. Liu, J. X. Chen and J. Y. Zhang, Chin. J. Chem. Eng., 2007, 15, 63.

49 F. Cárdenas-Lizana and M. A. Keane, J. Mater. Sci., 2013, 48, 543.

50 R. Wojcieszak, S. Monteverdi, J. Ghanbaja and M. M. Bettahar, J. Colloid Interface Sci., 2008, 317, 166.

51 J. Greeley and M. Mavrikakis, Nat. Mater., 2004, 3, 810.

52 J. Greeley and M. Mavrikakis, J. Phys. Chem. B, 2005, 109, 3460.

53 B. Pawelec, A. M. Venezia, V. La Parola, S. Thomas and J. L. G. Fierro, Appl. Catal., A, 2005, 283, 165.

54 X. Zhang, H. Shi and B.-Q. Xu, Catal. Today, 2007, 122, 330. 55 T. V. Choudhary, C. Sivadinarayana, A. K. Datye, D. Kumar and D. W. Goodman, Catal. Lett., 2003, 86, 1.

56 Y. Azizi, C. Petit and V. Pitchon, J. Catal., 2008, 256, 338.

57 F. Cárdenas-Lizana, X. Wang, D. Lamey, M. Li, M. A. Keane and L. Kiwi-Minsker, Chem. Eng. J., 2014, 255, 695.

58 V. Vishwanathan, V. Jayasri, P. M. Basha, N. Mahata, L. M. Sikhwivhilu and N. J. Coville, Catal. Commun., 2008, 9, 453.

59 K. K. Yeong, A. Gavriilidis, R. Zapf and V. Hessel, Catal. Today, 2003, 81, 641.

60 F. Cárdenas-Lizana, B. Bridier, C. C. K. Shin, J. Pérez-Ramírez and L. Kiwi-Minsker, ChemCatChem, 2012, 4, 668.

61 H. Duan, D. Wang, Y. Kou and Y. Li, Chem. Commun., 2013, 49, 303.

62 P. Lu and N. Toshima, Bull. Chem. Soc. Jpn., 2000, 73, 751.

63 P. Lu, T. Teranishi, K. Asakura, M. Miyake and N. Toshima, J. Phys. Chem. B, 1999, 103, 9673.

64 F. Cárdenas-Lizana, Z. Martínez de Pedro, S. Gómez-Quero and M. A. Keane, J. Mol. Catal., 2010, 326, 48.

65 C. Xiao, X. D. Wang, C. Lian, H. Q. Liu, M. H. Liang and Y. Wang, Curr. Org. Chem., 2012, 16, 280.

66 V. L. Khilnani and S. B. Chandalia, Org. Process Res. Dev., 2001, 5, 263.

67 K. Shimizu, Y. Miyamoto, T. Kawasaki, T. Tanji, Y. Tai and A. Satsuma, J. Phys. Chem. C, 2009, 113, 17803.

68 E.-J. Shin and M. A. Keane, J. Catal., 1998, 173, 450.

69 W. W. Lonergan, D. G. Vlachos and J. G. Chen, J. Catal., 2010, 271, 239.

70 T. Wang, G. Mpourmpakis, W. W. Lonergan, D. G. Vlachos and J. G. Chen, Phys. Chem. Chem. Phys., 2013, 15, 12156. 